\title{
Internal Migration and the Condition of Female Construction Workers: A Study in Chittagong City
}

\author{
Md. Akter Hossen ${ }^{1, *}$, Md. Arif Uddin Khan ${ }^{1}$, Zakia Sharmin ${ }^{1}$, \\ Tania Jannatul Kubra ${ }^{2}$ \\ ${ }^{1}$ Lecturer, Department of Sociology, Faculty of Social Science, University of Chittagong , Chittagong , \\ Bangladesh \\ ${ }^{2}$ M.S.S. Department of Sociology, Shahjalal University of Science and Technology, Sylhet, \\ Bangladesh \\ ${ }^{*}$ Cell phone - 01819349229 \\ *E-mail address: akterhossen@cu.ac.bd
}

\begin{abstract}
Women workers are found in certain activities traditionally falling within the male domain. This is particularly the case for landless women who largely belong to the hardcore poor group. It indicates growing economic pressure and erosion of familial support and traditional beliefs and norms regarding women's outside work. With the Bangladesh economy's heavy dependence on imports Chittagong has traditionally played a very important role in the trading sectors and industrial centre of the country and also commercial capital of Bangladesh which is going through a massive phase of construction of new structures. The study employed triangulation method as a research strategy. The objective of the study is to know the reasons of internal migrations and conditions of female construction workers of Chittagong city. A good number of rural women are involved at urban construction work in Chittagong city where they faces different harmful condition like as long working hour, less salary, lack of women rights, sexual harassment, food expenditure, low health condition, hard working etc. From this rational discussion this papers examine internal migration and the condition of migrant female construction works in Chittagong city.
\end{abstract}

Keywords: Internal Migration; Female Construction Worker; Harmful Condition; Chittagong city

\section{INTRODUCTION}

Bangladesh is one of the densely populated country of the world with a population of 158.5 million in a land mass of $1,47,570 \mathrm{sq}$ ' $\mathrm{kms}$. The economy is still agro based, with just under $50 \%$ of total labor force employed in the sector and more than $70 \%$ of the population involved directly or indirectly in agricultural activities. Labour Force Survey indicates that more than $95 \%$ of the 56.7 million individuals in the labour force (15+ Population) were employed in 2010 . About $49 \%$ of those who are in the agriculture sector, $17 \%$ are in the industry sector, and 34\% are in the services sector. Agriculture alone employs $49 \%$ of labour force, even though its Gross Domestic Product (GDP) share is only 18.6\% (Bangladesh 
Bureau of Statistics 2010). Inability of agriculture sector to absorb surplus labour force is one of the major causes of rural-urban migration. After agricultural workers, construction workers constitute the second most important flow of internal migrants in Bangladesh. The sector is considered an important driving force of development in the country. It contributed 8.3 per cent and 9.3 per cent to the GDP in FY2009-2010 and FY2011-2012, respectively. Its 6.5 per cent growth rate in 2010 is projected to increase to 8.6 per cent in 2015, according to the Bangladesh Bureau of Statistics. The 2010 growth rate is higher than that of agriculture sector (5.3 per cent) and very close to other two major sectors: manu- facturing (6.5 per cent) and service (6.5 per cent). The 6th Five Year Plan for Bangladesh projects that in 2015 the total number of people employed in construction will be around 2.9 million and also recognizes that Bangladesh is still a low income country with poverty, inequality, deprivation, climate change, unfavorable condition, joblessness etc. Social and economic change inherent within modernization yield increases in personal freedom and declines in the difficulties built-in breaking ties with residential origins. Thus; migrations of labor from rural to urban migration are an important part in Bangladesh. Internal migration from rural to urban areas has become a livelihood strategy adopted by an increasing number of families who migrate to the capital city in search of better employment opportunities. They move on their own, in groups or with siblings in search of job opportunities available in the city or to escape from abusive and oppressive situations at home. Like male counterparts in factories and other manufacturing units, female migrants in urban areas came predominately in search of employment. Most significant is the increase in female migration as independent migrants and not merely as associational migrants. According to the World Migration Report 2011, almost half of the estimated 175 million migrants worldwide are women. They migrate to the city for a certain period of time and then go back to the village. There are other women who do construction work at some times and stay in the city throughout the year.

\section{Background of the study}

Bangladesh at the present is $8^{\text {th }}$ most popular country in the globe. Like many others country, the rate of urban poor people in Bangladesh is increasingly High population, extreme poverty, scarce land, and natural resources increases in one hand and the problems associated with growing crops, livestock unemployment, domestic violence etc (PJSS,vol;32). As a result, thousands of people migrate in rural-urban areas every year. Majority the migrants are young males, but this significantly with the recent increase in demand for female poor workers (ADV, 2001; 10-11).Traditionally, women have played a vital role in the rural economics with their involvement in post-harvest activities as well as in food production from tilling to showing to harvesting. About $80 \%$ of post harvest work is done by women. Much of this work and indeed all the household chores that they routinely carry out remain unrecognized, unpaid for and invisible (Institute of Migration, 2011;15-17).This unorganized work is in effect the service and maintenance of the female workers of today and tomorrow (Giddens,1992;56). For better life and levels of benefits, the entry of poor women into the urban labor market, domestic help, informal industry worker, hotel/mess cook, service and other household etc (PJSS, vol 30;2). Thus women today have two recognized roles; one at home and the increasingly in the workplace (Giddens,1992;56). Bangladeshi women contribute substantially to their households and to the country's economy. The majority of poor women workers are migrated from rural-urban areas and they primarily involved in the 
informal sector of the economy. But women participation in economic activities shows great variations by gender, nature of activity and placed of destination. Self employed or own account workers are predominantly where men's involvement in sizeable (nearly a quarter) and women's negligible (Giddens, 1992; 11).

\section{Objectives}

Broader objective of this research paper is internal migration and the condition of female construction work in Chittagong city. This broader objective it is dividing into several specific objectives-1. To know the reasons of internal migration (natural disasters, lack of year round employment, job related, crop production suffering, social capital etc).

To know the working condition of female construction workers (working hour, salary, health condition, women rights, unsafe condition, sexual harassment, inequality and object of labor).

\section{Review of the Literature}

For the purpose of our discussion we classify the different review of literature into two parts. First part discusses the reason of the internal migration and second part discusses the condition of construction work. First part focus on the reasons of internal migration here we found that natural disasters (flood, cyclones), social capital, lack of year round employment, political clash, search the job, crop production suffering etc. Natural disaster is one of the major problem of internal migration of female workers in Bangladesh [ADBPD (2001), UN (1997) . Natural disaster such as floods, cyclones, draughts, deforestation, soil erosion, deprivation of traditional means of livelihood. Cyclones cause damage and deaths almost every year in Bangladesh. Several cyclones occurred in 1960, 1970, 1980, 1991 \& 1998, causing loss of millions of human lives, livestock and damage to infrastructures. In 1991, 85 percent of victims were women and children in some areas. On the other side floods occur every year in Bangladesh. Such conditions have pushed great numbers of poor women of their livelihood .Thus, women's suffers significantly during the natural disaster. [ADBPD, 2001; 28].There are relation between social capital \& internal migration Social capital or network provides is a useful network that can capture the range of economic \& non-economic processes which inhibit or allow the movement of people[PJSS (2010), Siddique (2003)]. Migration is not an atomistic reaction to economic or environmental pressure but it is embedded in societal rules and norms. So, social network in migration process is positive Because social network ties household together and provides support when illness strikes or money rules out [Uddin, 2010; 13]. Thus, it is clear that social network play on important role in migration process. Lack of year-round employment is another reason of internal migration of female worker [Migration Development Pro-poor Policy Choices in ASIA (2003)].The agricultural sector does not have enough scope to absorb large numbers of laborer. Rural areas are still lagged behind of industrialization and thus unemployment in the general feature of this country. The adult, young, adolescent and others children in rural areas did not find satisfactory employment [Afsar, 2003; 7]. So, people move to city area for looking employment. Political clash is also problematic reason for internal migration [PJSS (2010), 
Hunter (2004), ADBPD (2001)]. In the rural areas political clash, politics and political debate also compel people to migrate to the city. Some migrate have migrated to the town because they were minority groups, some have migrated to the town because their supported political party has been debated in the election and they feared the torture of rival party, some feared the case which might be filed against them and some faced the treat of life [Uddin, 2010;8].So, people migrate to city for political factors. Rural to urban migration is job related [WBPRWP (2006)] and it is natural to study migration in a detailed job search framework which allows to model migration and job search can account for a variety of patterns including the differences in unemployment duration among migrants the diversity of search choices or the selection of migrants to particular destination areas [Seld, Lall \& Shalizi,2006;23]. So, clearly to say that they often help later migrants to find a job, accommodation or set up a business. Crop production suffering is also a major reasons for rural-urban migration [Beaudouin(2006), $\operatorname{ADBPD}(20010]$.Crop is still the income generations activity But crop production suffers from many hazards. Agricultural activities still presents the major part of the income of the household. However this activity can particularly suffer from migration. So, migration decision is no more view only as income maximization but also as a risk minimization. Almost universally, women migrate to provide financial support for their families.

Second part focus on the condition of construction work here we found that lack of women rights, less salary, long working hour, unsafe condition, sexual harassment, low health condition \& production process). Health condition of construction female workers is slightly lower [ADBPD(2001)]. Women are more disadvantaged than men in terms of access to health care in construction work place. Unlike most countries of the world, life expectancy of Bangladesh is slightly lower than men. Women family members are less likely to receive modern medical care and they generally rely on traditional and cheap methods of health care in construction work place [Afsar,2003;8]. So, health condition is problematic for female workers in construction work place. The lack of women rights to held construction work place them in a very insecure position, especially in the event of crisis and can deprive them of the benefits of development assistance [Hossain (2009]. Although the proportion of female causal laborers increased significantly in urban areas and in all areas self-employment increased but situation with regard to minimum wage and women wages in the construction sector. Slum dwellers who are predominantly migrants from rural areas, earned around one third of the income of the slum households in 1991; this declined to one fifth in 1998 [Afsar, 2003; 7]. So, inequality increases day by day in construction work place. Most women construction sector work long hours with few days off [ADBPD (2001)]. Subsequently they face the problem of physical strain that is aggravated by low earnings/low profit margins generated from informal sector activities despite their hard work. Although women worked $75 \%$ more hours per week than their male counterparts, they received only about three fifths of the wage paid to male contract/day laborers [ADBPD, 2001; 28]. So, it is clearly to say that the time spent and the income earned by women in the construction sector varied greatly by the nature, of their involvement, by gender, and place of residence of female workers. Unsafe condition is another problematic condition of construction work place [Giddens(1992)]. A highly competitive labor markets demands regular and timely participation that often becomes different for women to fulfill. Moreover, the greatest obstacle women face in the informal sector is their low access to resources. They lack the capital required for building the 
permanent structures of the enterprise labor saving tools to ease domestic burden and raw materials and improved machineries needed to increase productivity in construction sector [Giddens,1992;28]. In addition, to say that the lack of cheap, safe transportation harassment by employers and police, problems with middlemen etc, are the other constraints faced by women in the construction work place. Construction female workers are especially vulnerable to sexual harassment $[\mathrm{CPD}(2004)]$. Reasons of sexual harassment is informal practices of recruitment, lack of documentation of hiring and firing, and the constant fear of jobless. If a worker is verbally or physically abused or publicly humiliated of mistakes, the ensuring fear and anxiety increases the likelihood of mistakes in her work which affect her productivity. So, female workers face sexual harassment in their construction work place through fear, anxiety, depression and hopelessness. Reviewing about the crisis of construction female workers at last to say that, here seems to increases their level of tolerance to violence of internal migration.

\section{Theoretical Framework}

Study of internal migration is a key importance in social sciences and it emerges not only the movement of people between one place to another place inside the country but also influences on livelihoods and urban growth. Among different theories for migration, pushpull theory is the most frequently heard enlightenment. Some people are pushed out to move from their prior locality while others have been pulled or magnetized to some others places else. This idea was first launched by Ravenstein in 1889 who suggested that among push \& pull factors. Here is pull factors were more important. Because, in migration the push factors may be low wages, political turmoil, low living standards and the pull factors may be the higher wages, high living standards, decreasing political violence and demand for specific skills set and knowledge [Institute of Migration,201;17]. In this way people voluntarily migrated because of the aspiration to get forward more than the desire to get away from the unpleasant situation. It improved remarkably in urban areas, suggesting a greater volume workers independent migration to cities. But women workers in informal sector are typically employed in a narrow range of occupations, characterized by high job insecurity, low pay, bad working conditions, low status and minimal bargaining power. Most of Bangladeshi women's are involved in the construction work place and directly or indirectly they facing these harmful condition. So, Internal migration and the condition of female construction work in Chittagong city" is main objective of this research paper. 


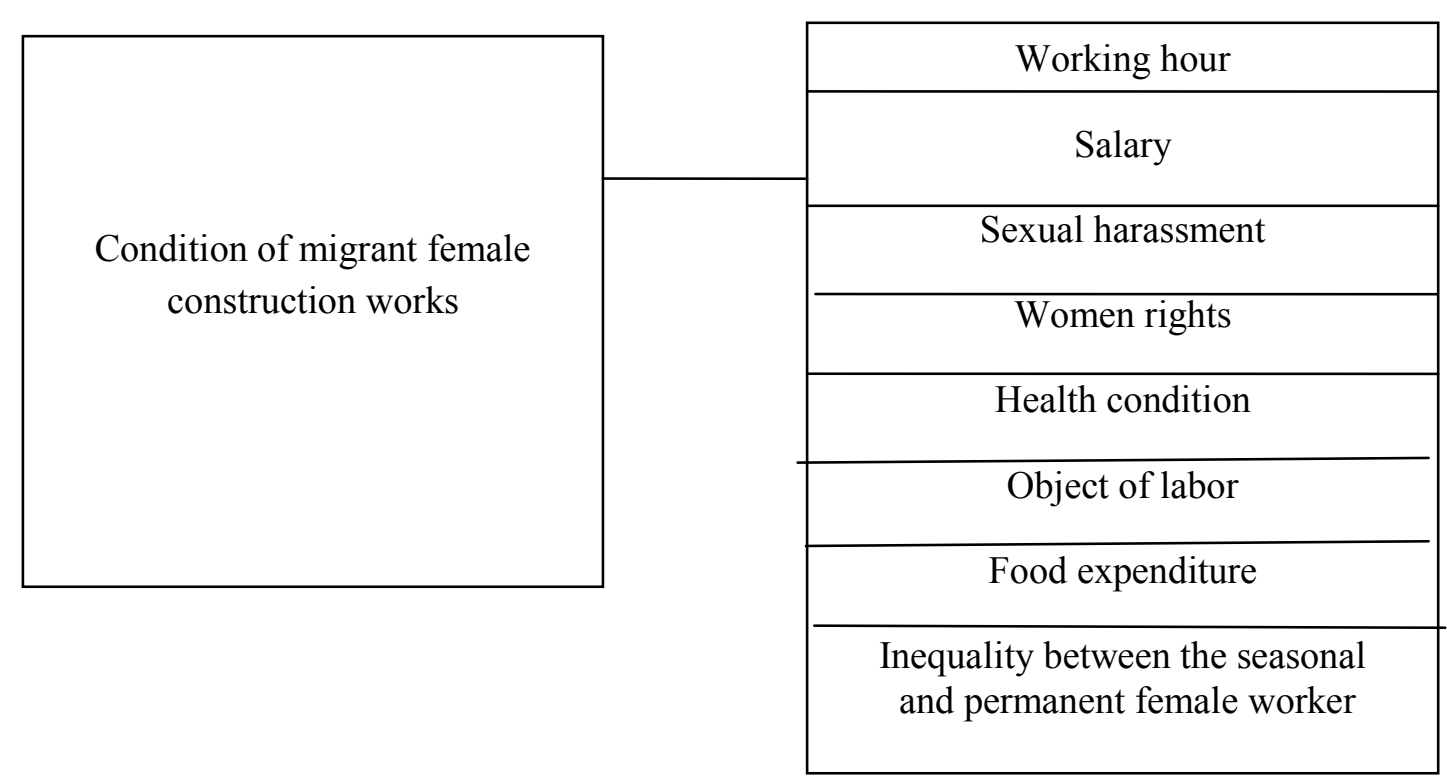

Fig. 1. Conceptual Model.

\section{Methodology}

In this research, descriptive design has been followed. This study works to descriptive the internal migration \& social crisis of construction female workers in Chittagong city. The study employed triangulation method (both Quantitative \& qualitative) as a research strategy. This study is used case study to analyses the qualitative data $\&$ survey method is for quantitative data. Construction work place of ruphabad, azad kolony (cholkhola rail crossing), khulshi kolony(technical area), shershah banglabazar, bishsow colony (a.k.khan) in Chittagong city is selected for study area. All the female construction workers in Chittagong city are selected as the population of the study. In this study purposive sampling is used as a part of non-probability sampling. Purposively sample size is selected from the population for study. Each of the construction female workers in the study area are selected as unit of analysis. In this study survey method and case study (methodological triangulation) used for this study by selecting a representative way a sample of individual. Close \& open ended questionnaire are used of the survey method. Various statistical measurements are used to analyze the collected data like percentage \& table. SPSS software is used as a technique of data analysis. 


\section{RESULTS AND DISCUSSION}

\begin{tabular}{|c|c|c|c|c|c|}
\hline \multicolumn{2}{|l|}{ Table 1.} & Frequency & $\%$ & Valid \% & Cumulative $\%$ \\
\hline \multirow{19}{*}{$\begin{array}{l}\text { Age of the } \\
\text { respondent }\end{array}$} & 25 & 1 & 2.0 & 2.0 & 2.0 \\
\hline & 27 & 2 & 4.0 & 4.0 & 6.0 \\
\hline & 28 & 5 & 10.0 & 10.0 & 16.0 \\
\hline & 29 & 5 & 10.0 & 10.0 & 26.0 \\
\hline & 30 & 7 & 14.0 & 14.0 & 40.0 \\
\hline & 31 & 1 & 2.0 & 2.0 & 42.0 \\
\hline & 32 & 3 & 6.0 & 6.0 & 48.0 \\
\hline & 33 & 4 & 8.0 & 8.0 & 56.0 \\
\hline & 34 & 2 & 4.0 & 4.0 & 60.0 \\
\hline & 35 & 4 & 8.0 & 8.0 & 68.0 \\
\hline & 36 & 2 & 4.0 & 4.0 & 72.0 \\
\hline & 37 & 1 & 2.0 & 2.0 & 74.0 \\
\hline & 38 & 1 & 2.0 & 2.0 & 76.0 \\
\hline & 39 & 2 & 4.0 & 4.0 & 80.0 \\
\hline & 40 & 4 & 8.0 & 8.0 & 88.0 \\
\hline & 42 & 3 & 6.0 & 6.0 & 94.0 \\
\hline & 45 & 2 & 4.0 & 4.0 & 98.0 \\
\hline & 46 & 1 & 2.0 & 2.0 & 100.0 \\
\hline & Total & 50 & 100.0 & 100.0 & \\
\hline
\end{tabular}




\begin{tabular}{|c|c|c|c|c|c|}
\hline \multicolumn{2}{|l|}{ Table 2.} & Frequency & $\%$ & Valid \% & $\begin{array}{c}\text { Cumulative } \\
\%\end{array}$ \\
\hline \multirow{3}{*}{$\begin{array}{c}\text { Valid } \\
\text { Educational } \\
\text { qualification of the } \\
\text { respondent }\end{array}$} & Illiterate & 17 & 34.0 & 34.0 & 34.0 \\
\hline & $\begin{array}{l}\text { literate without } \\
\text { formal schooling }\end{array}$ & 19 & 38.0 & 38.0 & 72.0 \\
\hline & Primary & 14 & 28.0 & 28.0 & 100.0 \\
\hline \multirow{5}{*}{$\begin{array}{l}\text { Marital status of the } \\
\text { respondent }\end{array}$} & Married & 2 & 4.0 & 4.0 & 4.0 \\
\hline & Unmarried & 6 & 12.0 & 12.0 & 16.0 \\
\hline & Divorced & 13 & 26.0 & 26.0 & 42.0 \\
\hline & Widow & 16 & 32.0 & 32.0 & 74.0 \\
\hline & Separation & 13 & 26.0 & 26.0 & 100.0 \\
\hline \multirow{7}{*}{$\begin{array}{l}\text { Salary of the } \\
\text { respondent }\end{array}$} & 150 & 2 & 4.0 & 4.0 & 4.0 \\
\hline & 180 & 1 & 2.0 & 2.0 & 6.0 \\
\hline & 200 & 19 & 38.0 & 38.0 & 44.0 \\
\hline & 220 & 16 & 32.0 & 32.0 & 76.0 \\
\hline & 230 & 1 & 2.0 & 2.0 & 78.0 \\
\hline & 240 & 5 & 10.0 & 10.0 & 88.0 \\
\hline & 250 & 6 & 12.0 & 12.0 & 100.0 \\
\hline \multirow{6}{*}{$\begin{array}{l}\text { Reason of the } \\
\text { respondent }\end{array}$} & natural disasters & 5 & 10.0 & 10.0 & 10.0 \\
\hline & lack of year round & 12 & 24.0 & 24.0 & 34.0 \\
\hline & political clash & 3 & 6.0 & 6.0 & 40.0 \\
\hline & job related & 12 & 24.0 & 24.0 & 64.0 \\
\hline & $\begin{array}{l}\text { crop production } \\
\text { sufferings }\end{array}$ & 5 & 10.0 & 10.0 & 74.0 \\
\hline & social capital & 13 & 26.0 & 26.0 & 100.0 \\
\hline \multirow{2}{*}{ Job of the respondent } & Permanent & 8 & 16.0 & 16.0 & 16.0 \\
\hline & Seasonal & 42 & 84.0 & 84.0 & 100.0 \\
\hline \multirow{3}{*}{$\begin{array}{l}\text { Work time of the } \\
\text { respondent }\end{array}$} & 8 & 6 & 12.0 & 12.0 & 12.0 \\
\hline & 9 & 25 & 50.0 & 50.0 & 62.0 \\
\hline & 10 & 19 & 38.0 & 38.0 & 100.0 \\
\hline \multirow{3}{*}{$\begin{array}{l}\text { Off day of the } \\
\text { respondent }\end{array}$} & half day & 8 & 16.0 & 16.0 & 16.0 \\
\hline & full day & 8 & 16.0 & 16.0 & 32.0 \\
\hline & Don't Get & 34 & 68.0 & 68.0 & 100.0 \\
\hline \multirow{2}{*}{$\begin{array}{l}\text { Facing sexual } \\
\text { harassment of the } \\
\text { respondent }\end{array}$} & Yes & 30 & 60.0 & 60.0 & 60.0 \\
\hline & No & 20 & 40.0 & 40.0 & 100.0 \\
\hline \multirow{2}{*}{$\begin{array}{l}\text { Facing theft of the } \\
\text { respondent }\end{array}$} & Yes & 30 & 60.0 & 60.0 & 60.0 \\
\hline & No & 20 & 40.0 & 40.0 & 100.0 \\
\hline \multirow{2}{*}{$\begin{array}{l}\text { Primary treatment from } \\
\text { construction work place }\end{array}$} & Yes & 15 & 30.0 & 30.0 & 30.0 \\
\hline & No & 35 & 70.0 & 70.0 & 100.0 \\
\hline \multirow{2}{*}{$\begin{array}{l}\text { live in construction work } \\
\text { place of the respondent }\end{array}$} & Yes & 9 & 18.0 & 18.0 & 18.0 \\
\hline & No & 41 & 82.0 & 82.0 & 100.0 \\
\hline \multirow{3}{*}{$\begin{array}{l}\text { Sanitation system in } \\
\text { work place of the } \\
\text { respondent }\end{array}$} & Good & 3 & 6.0 & 6.0 & 6.0 \\
\hline & Medium & 11 & 22.0 & 22.0 & 28.0 \\
\hline & $\mathrm{Bad}$ & 36 & 72.0 & 72.0 & 100.0 \\
\hline
\end{tabular}




\begin{tabular}{|c|c|c|c|c|c|}
\hline \multicolumn{2}{|l|}{ Table 3.} & Frequency & $\%$ & Valid \% & Cumulative \% \\
\hline \multirow{2}{*}{$\begin{array}{c}\text { Valid } \\
\begin{array}{c}\text { Get salary system of the } \\
\text { respondent }\end{array}\end{array}$} & per day & 41 & 82.0 & 82.0 & 82.0 \\
\hline & per week & 9 & 18.0 & 18.0 & 100.0 \\
\hline \multirow{6}{*}{$\begin{array}{l}\text { Overtime facility of the } \\
\text { respondent }\end{array}$} & Yes & 14 & 28.0 & 28.0 & 28.0 \\
\hline & No & 36 & 72.0 & 72.0 & 100.0 \\
\hline & $60-80$ taka & 4 & 8.0 & 8.0 & 8.0 \\
\hline & 90-100 taka & 8 & 16.0 & 16.0 & 24.0 \\
\hline & $\begin{array}{c}110-120 \\
\text { taka }\end{array}$ & 2 & 4.0 & 4.0 & 28.0 \\
\hline & $\begin{array}{c}\text { not overtime } \\
\text { salary }\end{array}$ & 36 & 72.0 & 72.0 & 100.0 \\
\hline \multirow{4}{*}{ Get nutriment of the respondent } & Egg & 3 & 6.0 & 6.0 & 6.0 \\
\hline & Fish & 4 & 8.0 & 8.0 & 14.0 \\
\hline & Vegetable & 8 & 16.0 & 16.0 & 30.0 \\
\hline & Don't get & 35 & 70.0 & 70.0 & 100.0 \\
\hline \multirow{2}{*}{$\begin{array}{l}\text { Food from work place of the } \\
\text { respondent }\end{array}$} & Yes & 13 & 26.0 & 26.0 & 26.0 \\
\hline & No & 37 & 74.0 & 74.0 & 100.0 \\
\hline \multirow{2}{*}{$\begin{array}{l}\text { Satisfaction about the health of } \\
\text { the respondent }\end{array}$} & Yes & 7 & 14.0 & 14.0 & 14.0 \\
\hline & No & 43 & 86.0 & 86.0 & 100.0 \\
\hline \multirow{2}{*}{$\begin{array}{l}\text { Advice about health from work } \\
\text { place of the respondent }\end{array}$} & Yes & 7 & 14.0 & 14.0 & 14.0 \\
\hline & No & 43 & 86.0 & 86.0 & 100.0 \\
\hline \multirow{4}{*}{$\begin{array}{l}\text { Get off time in work place of } \\
\text { the respondent }\end{array}$} & $30 \mathrm{~min}$ & 30 & 60.0 & 60.0 & 60.0 \\
\hline & $1 \mathrm{hrs}$ & 12 & 24.0 & 24.0 & 84.0 \\
\hline & $2 \mathrm{hrs}$ & 5 & 10.0 & 10.0 & 94.0 \\
\hline & Don't get & 3 & 6.0 & 6.0 & 100.0 \\
\hline \multirow{3}{*}{$\begin{array}{l}\text { Object of labor of the } \\
\text { respondent }\end{array}$} & $\begin{array}{c}\text { break of } \\
\text { brick }\end{array}$ & 27 & 54.0 & 54.0 & 54.0 \\
\hline & carry of soil & 14 & 28.0 & 28.0 & 82.0 \\
\hline & $\begin{array}{l}\text { carry of sand } \\
\text { or }\end{array}$ & 9 & 18.0 & 18.0 & 100.0 \\
\hline \multirow{2}{*}{$\begin{array}{l}\text { Get pure water of the } \\
\text { respondent }\end{array}$} & Yes & 9 & 18.0 & 18.0 & 18.0 \\
\hline & No & 41 & 82.0 & 82.0 & 100.0 \\
\hline \multirow{2}{*}{$\begin{array}{l}\text { Inequality present in the } \\
\text { construction work place }\end{array}$} & Yes & 40 & 80.0 & 80.0 & 80.0 \\
\hline & No & 10 & 20.0 & 20.0 & 100.0 \\
\hline \multirow{2}{*}{$\begin{array}{l}\text { Can complaint to owner of the } \\
\text { respondent }\end{array}$} & Yes & 9 & 18.0 & 18.0 & 18.0 \\
\hline & No & 41 & 82.0 & 82.0 & 100.0 \\
\hline \multirow{2}{*}{$\begin{array}{l}\text { Facing accident of the } \\
\text { respondent }\end{array}$} & Yes & 34 & 68.0 & 68.0 & 68.0 \\
\hline & No & 16 & 32.0 & 32.0 & 100.0 \\
\hline
\end{tabular}


In the construction work place, whose are migrant female worker them are the $2 \%$ of 25 age, $4 \%$ of 27 age, $10 \%$ of 28 age, $10 \%$ of 29 age, $14 \%$ of 30 age, $2 \%$ of 31 age, $6 \%$ of 32 age, $8 \%$ of 33 age, $4 \%$ of 34 age, $8 \%$ of 35 age, $4 \%$ of 36 age, $2 \%$ of 37 age, $2 \%$ of 38 age, $4 \%$ of 39 age, $8 \%$ of 40 age, $6 \%$ of 42 age, $4 \%$ of 45 age $\& 2 \%$ of 46 age. Among them are the $34 \%$ are illiterate, $38 \%$ are literate without formal schooling \& $28 \%$ are primary educated. Among the female worker $4 \%$ are married, $12 \%$ are unmarried, $26 \%$ are divorced, $32 \%$ are widow \& $26 \%$ are separated. (Table $1,2 \& 3$ ). In the case of internal migration here we see that reason of natural disasters, lack of year round employment, political clash, job related, crop production sufferings and social capital female worker came into the Chittagong city. Seem to that, reason of $10 \%$ are natural disasters, $24 \%$ of lack of year round employment, $6 \%$ of political clash, $24 \%$ of job related, $10 \%$ of crop production sufferings \& $26 \%$ of social capital came into the Chittagong city (Table 5). In the analysis working condition of female construction workers here we analyses the working hour, salary, health condition, women rights, unsafe condition, sexual harassment, food expenditure, inequality and object of labor. In the analyses of working hour to say that $12 \%$ female worker do the work $8 \mathrm{hrs}, 50 \%$ do the work $9 \mathrm{hrs} \& 38 \%$ do the work $10 \mathrm{hrs}$ (Table 7 ). In the study of salary to say that, $4 \%$ female workers get salary 150 taka, $2 \%$ are get salary 180 taka, $38 \%$ are get salary 200 taka, $32 \%$ are get salary 220 taka, $2 \%$ are get salary 230 taka, $10 \%$ are get salary 240 taka \& $12 \%$ are get salary 250 taka (Table 4) . Among the female worker $82 \%$ get salary per day and $18 \%$ get salary per week (Table 14). In the analysis of health condition here seems that $14 \%$ of the female workers are satisfied about health care facility and $86 \%$ of the female worker are not satisfied about the health care facility (Table 19). Among the female workers $30 \%$ get primary treatment from construction work place and 70\% workers don't get primary treatment from the construction work place (Table 11). Here also see that $14 \%$ of workers get advice about health from work place and $86 \%$ of workers don't get advice about health from construction work place (Table 20). In the analysis of women rights here we seem that $18 \%$ of female worker can complaint to owner and $82 \%$ of female worker can't complaint to owner when they faces sexual harassment (Table 21). Among the female worker here we see that $60 \%$ of female worker get 30min off time in work place, $24 \%$ of female worker get $1 \mathrm{hrs}$ off time, $10 \%$ of female worker get $2 \mathrm{hrs}$ off time and $6 \%$ don't get off time in work place (Table 25 ). Here $16 \%$ of female worker are permanent worker and $84 \%$ of female worker are seasonal worker (Table 6). And also we found that $16 \%$ of female worker get half day off, $16 \%$ of female worker get full day off and $68 \%$ of female worker don't get any off day (Table 8 ). From survey data here we found that $18 \%$ of female live in the construction work place and $82 \%$ of female worker don't live in the construction work place (Table 12). In the case of get overtime facility here we seem that $28 \%$ of female get overtime facility and $72 \%$ of female worker don't get overtime facility (Table 15). Among the female worker here also found that $8 \%$ of female worker get $60-80$ taka salary of overtime, $16 \%$ get $90-100$ taka, $4 \%$ get $110-120$ taka and $72 \%$ of female worker don't get any overtime salary (Table 16). In the analysis of unsafe condition here we found that $60 \%$ of female worker facing theft and $40 \%$ of female worker don't facing any theft in the construction work place. In the case of facing accident here see that $68 \%$ of female worker facing accident and $32 \%$ of female worker don't facing accident in the construction work place (Table 26) The Bangladesh Labour Law (2006) is the main instrument for the protection of workers. The law states that every employer is obliged to provide compensation to workers in the case of injury, disability or death, due to workplace accidents. The law states that the family of a deceased worker resulting from a workplace 
accident will receive taka 100,000 as compensation, and will receive taka 125,000 for a permanently disabled worker. Other important entitlements that workers are deprived of social security benefits, such as insurance and maternity benefits. Here we see that $18 \%$ of female worker get pure water and $82 \%$ of female worker don't get pure water in the construction work place (Table 23). From survey data here we found that $6 \%$ of sanitation system is good, $22 \%$ of sanitation system is medium and $72 \%$ of sanitation system is bad in the construction work place (Table 13). In the analysis of sexual harassment here we seem that $60 \%$ of female worker facing sexual harassment and $40 \%$ of female worker don't facing sexual harassment in the construction work place (Table 9). In the study of food expenditure here we see that $6 \%$ of female worker get egg as a nutriment, $8 \%$ of female worker get fish as a nutriment, $16 \%$ of female worker get vegetable as a nutriment and $70 \%$ of female worker don't get any nutriment (Table 17). Among the female worker $26 \%$ get food from work place and $74 \%$ don't get food from work place (Table 18). In the analysis of inequality in work place here we see that $80 \%$ of female worker said yes and $20 \%$ of female worker said no (Table 24).In the analysis of object of labor here we found from the survey data that $54 \%$ of female worker do the work break of brick, $28 \%$ of female worker do the work carry of soil and $18 \%$ of female worker do the work carry of sand or gravel (Table 22 ).

\section{Case study}

Case study 1: Yasmin is a 40 years old and she is widow. She came from Netrokona. She migrated to Chittagong city with her children after her husband died. She come to construction work place in 8 a.m. and again back to home in 5 p.m. About the sexual harassment she says that, sexual harassment is very common in this place. But I have never experienced such a thing. She also says that I do the very hard working but I was not at all happy to salary. In this place male workers earn much salary than the female workers. In the case of sanitation facility she says that there all workers use open place for latrin. About the security system Yasmin says that here are no any security systems for workers, but i obliged to work in the construction place for livelihood.

Case study 2: Ruhela is a 33 year old. She is illiterate. She came from Jessore before 23 years with her husband. She is a seasonal migrant who does construction work with other members of her community in Chittagong. In the case of salary she says that, we don't get any overtime facility and there amount of salary is low than the working hour. About the sexual harassment she says that, we go to work in all kind of places and there is misbehavior, particularly while getting into the construction work place. But we do not take any nonsense. About the security system she says that, job are not available for poor women for this reason we are obliged to work in the construction work place like as unsecured place.

Case Study 4: Shashi is a 45-year-old woman who migrated to Chittagong from Barishal. She now lives with her husband and five children, of which four are girls and one boy. She says that I came in this city because of economic reasons. I didn't have land in the village. There people would speak badly, if we moved and worked outside the home they would say "what kind of a daughter-in-law is she?! She also says that, when I first came here, 
I didn't have any good/secure job". At last I obliged to hard working in the construction work place. In the case of production process she says that, in the construction work place I do the very hard working like as break of brick. About the opportunities she says that here are no any overtime facilities, About the amount of salary she says that, we work hard the whole day $\&$ after coming back home in the evening. But they give us 160 taka only \& male workers get 300 taka only. She also says that, we are looking to girls, we don't less work than the male worker. For less amount of salary, I can't improve my poverty condition. Here if you are absent, they say settle the accounts and leave.

\section{CONCLUSION}

Migrants women construction workers come from that section of the society which must work to earn their livelihood and which is socially, economically and traditionally backward and least privileged.The findings of the study show that many women construction workers are illiterate, widows, only earning members of the family, from depressed class and from low income families when compared to men construction workers. Women construction workers face harassment at home and work place, doing job a poor working conditions, lack of infrastructures and security, inadequate health service utilization made these workers a vulnerable population and they are discriminated in wages, nature of work, availability of work, on the basis of sex . Bargaining power is mostly with the employers, so exploitation is naturally the fate of these poor workers. They do not know about possible conditions of their job after migrating in city and also appointed verbally, There has no insurance for female construction workers, Injured or death workers get lump-sum compensation, It also depends on willing of employer. The findings of the study also show that they are not given an opportunity to be trained informally like men in the construction Industry. It may be said that the women construction workers are working in an unorganized sector and special policies need to be initiated to protect this group. From this study it was seen that to include conditions of female construction workers like wages, irregular payment, exploitation by labour leader, job insecurity, poor safety measures, lack of accidental compensation. ,To ensure insurance and standard compensation and advocacy with employer for well- beings of female construction workers . Hence this study recommends a comprehensive, universal and integrated Social Security System for these unorganized construction workers. The scenario only can be changed with the government intervention, by implementing the policies strictly. The status of the women only can be improved when major transition in the society occurs and that can be achieved by mind set transition. We must remember that by ignoring these women workers we are ignoring important contributors to national income of the country. 


\section{References}

[1] ADV (2001) Country Briefing Paper. August 2001. Asian Development Bank . Programs Development(WEST).

[2] Afsar, Rita (2003) Development and Pro-Poor Policy Choices in Asia. In : Proceedings of the Regional Conference on Migration, Dhaka, 22-24 June 2003, Bangladesh : Refugee and Migratory Movements Research Unit. PP. 1-16.

[3] Beaudouin , Pierre Yves (2006) Economic Impact of Migration on Rural Area in Bangladesh (Paris). Available from http://team.univ-Paris1.fr/teamperso/beaudouin.

[4] Bhenede, Dr (Mrs.) Asha A \& Kanitkar Prof.(Mrs.)Tara (1978) Principles of Population Studies. Himalaya Publishing House.Girgaon.Bombay.

[5] CPD (2004) CPD Dialogue Report. Report no 65.March 2004.Dhaka, Bangladesh.

[6] Giddens, Anthony (1992) Human Societies An Introductory Reader in Sociology. Polity Press. Cambridge.

[7] Haider, Sheikh Kabir Uddin (2010) Factors of Migration on Urban Bangladesh : An Empirical Study of Poor Migrants in Rajshahi Cty. Pakistan Journal of Social Sciences. Vol.30, No 2: PP 307-323.

[8] Haque, M.Ershadul and Islam, M. Mazharul (2012) Rural to Urban Migration and Household Living Conditions in Bangladesh. Dhaka Univ.J.Sci 60(2) : PP 253-257.

[9] Hassan, Mohammad Izhar (2005) Population Geography. Rawat Publications. Daraganj.New Delhi.India.

[10] Hossain, Mazhad (2009) Informal Economy, Governance and Corruption: Philippine Journal of Development. November 60 Second Semester 2005. Volume 32. No-2.

[11] Hunter, Lori M.(2005) Migration and Environmental Hazards. Population and Environment. Vol.26. Sprinfer science+Business Medin,Inc. In: University of Colorado. Boulder, PP 273-302.

[12] IM (2011) Web Reports. Report no 68. February 2011. Finland: Institute of Migration.

[13] WB (2006) World Bank Policy Research Working Paper. May 2006. USA: The World Bank.

[14] WWW.World Population Review.com (accessed : $15^{\text {th }}$ November 2014)

[15] Bangladesh Bureau of Statistics (BBS), (2010), Labour Force Survey 2010

[16] Bangladesh Institute of Labour Studies 2013, Bangladesh Institute of Labour Studies (BILS). 